\title{
The Determinant of Money Laundering: Evidence from Italian Regions
}

\author{
Filippo Reganati ${ }^{1}$, Maria Oliva ${ }^{2}$ \\ ${ }^{1}$ Department Digef, Sapienza, Rome, Italy \\ ${ }^{2}$ Economics and Financial Market freelance journalist, Rome, Italy \\ E-mails: 1filippo.reganati@uniroma1.it; ${ }^{2 m a r i a-o l i v a @ l i v e . i t ~}$
}

Received 10 February 2017; accepted 24 March 2017

\begin{abstract}
Following the INTERPOL's definition, money laundering is: "any act or attempted act to conceal or disguise the identity of illegally obtained proceeds so that they appear to have originated from legitimate sources". Illegally obtained funds are laundered and moved around the world using front companies, intermediaries and other money transmitters. In this way, the illegal funds remain hidden and are integrated into the legal economy. Such type of crime undermines financial institutions' and jurisdictions' reputation, compromises investors' trust in them, and therefore weakens the entire financial system. By using annual data for the Italian regions (NUTS-2) over the period 2008 to 2015 , this work aims to investigate the determinants of money laundering in Italy. Given the high heterogeneity in terms of economic and institutional characteristics, as well as for the activity of organized crime in financial-related activities, Italy is a compelling case study. Our main findings reveal that in most of the Italian regions enforcement activities do exert significant deterrence on criminal behaviors: a negative relationship between enforcement and illegal trafficking of waste can be identified only for very high levels of enforcement efforts. Moreover, we find that the major determinants influencing the rate of money laundering differ between northern-central and southern regions, confirming the existence of a regional dualism. In particular, while in the northern-central area the crime rate is positively related to the level of corruption, the incidence of mafia-type crimes and negatively to the education attainment, in the southern regions money laundering is positively related to the size of the gaming and gambling sector.
\end{abstract}

Keywords: financial flows, money laundering, law enforcement, organized crime.

JEL Classification: F23, F36, G15.

Conference topic: Contemporary Financial Management.

\section{Introduction}

Money laundering represents the process of taking the proceeds generated by criminal activity and giving such proceeds an appearance of legality ${ }^{1}$. Money laundering not only allows criminals to move their money through society freely, without attracting attention to the underlying activity or the persons involved but also prevents the funds from being confiscated by the judiciary authority ${ }^{2}$. The IMF estimates that the amount of money laundered globally in one year is between 2 and 5 per cent of global GDP, or roughly U.S. \$1-2 trillion annually. According to the United Nations Office on Drugs and Crime (UNODC), in 2009 criminals have laundered around US\$ 1.6 trillion which corresponds to 2.7 per cent of the global GDP.

Traditionally, money laundering has been described as a process that takes place in three distinct stages. In the initial - or placement - stage, money launderers introduce their illegal proceeds into the financial system through deposits, wire transfers, or other means. In the second - or layering - stage, money launderers move such funds around the world to separate them from their original source. Finally, in the third - integration - stage money launderers reenter funds into the legitimate economy investing them into real estate, luxury assets, or other business ventures.

\footnotetext{
${ }^{1}$ The term money laundering was coined by the Guardian during the Watergate Scandal and was referring to the illegal movement of US President Nixon's campaign contributions to Mexico and then back to the US through a company in Miami.

${ }^{2}$ Huge amounts of proceeds are generated by illegal arms sales, smuggling, and the activities of organised crime, such as drug trafficking and prostitution rings. Other activities such as embezzlement, insider trading, and bribery can also produce large profits and create a stimulus to "legitimise" the ill-gotten gains through money laundering.
} 
Money laundering might determine severe economic consequences for a country (Schneider, Windischbauer 2010). Using front companies to disguise the ill-gotten gains, money launderers might crowd out legitimate firms that suffer a competitive disadvantage vis-à-vis firms that do not draw capital funds from legal financial markets. In addition, the investments of money launderers are mainly driven by the desire of hiding their proceeds instead of making profits; this implies that such investments might be of a low quality and/or not economically beneficial to the country ${ }^{3}$.

The main purpose of this paper is to analyse the determinants of the money laundering in Italy using a panel dataset over the period 2008-2015. Given the high heterogeneity in terms of economic, social and institutional characteristics, as well as for the activity of organized crime, Italy is a compelling case study. In this context, we attempt to answer the following research questions: i) what are the main factors driving this type of crime. ii) To what extent is the existing enforcement system effective in deterring it? iii) Is there any degree of territorial heterogeneity on the determinants of money laundering?

The present study contributes to the extant literature on the economics of crime in several ways. First, it explicitly analyzes a specific type of financial crime, which presents the higher degree of sanctioning regime in the Italian legislation. Second, Italy represents a quite important country study because of the strong presence of mafia clans and organized crime systems operating in the illegal market. The remainder of the paper proceeds as follows. Section 2 outlines some stylized facts about money laundering in Italy. Section 3 reviews the main theoretical and empirical literature and points out some hypothesis to be tested. Section 4 describes the dataset and the empirical model, while the results are illustrated in Section 5. Finally, Section 6 summarizes and concludes the paper.

\section{Some stylized facts about money laundering in Italy}

The incidence and the evolution of money laundering in Italy can be illustrated with some descriptive statistics that refer to the number of violations denounced at the Authorities (Fig. 1). Starting from 2011 the level of offences has sharply increased. A possible explanation can be due to the change in the Italian legislation on money laundering (D.lgs. 231/2007) that has been approved in Italy after the third anti-money laundering European Directive.

In particular, this law has obliged not only the credit institutions (bank, postal, insurance, e-money institutions) and the financial ones institutions (trust companies, promoters, brokers), but also - and this is the most significant novelty - several legal or natural persons acting in the exercise of their professional activities (i.e., auditors, external accountants and tax advisors, notaries and independent legal professionals, trust or company service providers, real estate agents, casinos, etc.). The above-mentioned categories are attributed to the following obligations: i) adequate customer due diligence (arts. 15-35), ii) registration (arts. 36-40), and iii) reporting (arts. 41-48).

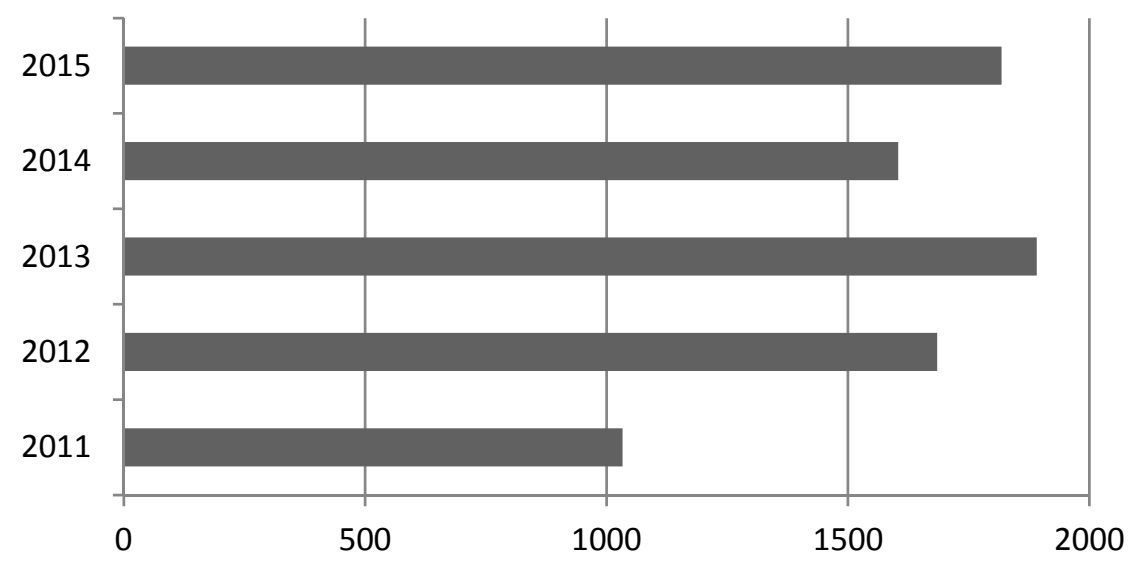

Fig. 1. Number of offences denounced by law enforcement at the authority of justice (2011-2015) (Source: ISTAT 2017)

Although we can observe a greater crime emergence, the exchange of knowledge and information between institutions and control authorities has been effective in slowing down the crime incidence in every single Italian region (Fig. 2). The emergence of money laundering is higher particularly in Lombardia, Piemonte and Liguria for the North of Italy; Toscana and Lazio, for the Centre of Italy; Campania, Sicilia and Puglia for the South of Italy.

\footnotetext{
${ }^{3}$ This can be the case when some industries (i.e. hotels) are financed only for a short-term and then abandoned, causing a collapse of these sectors.
} 


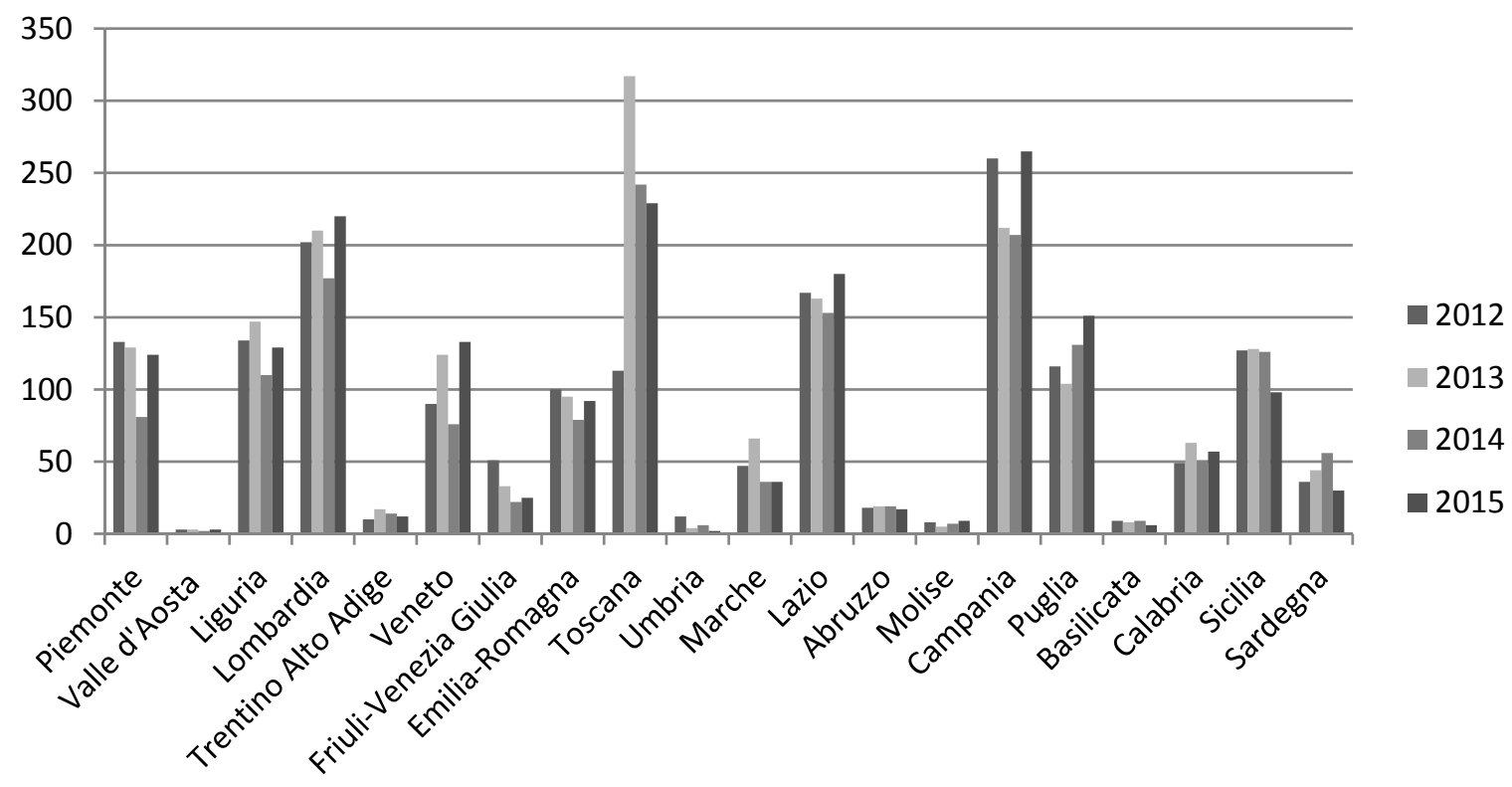

Fig. 2. The total number of reported case of offences denounced by law enforcement at the authority of justice (2012-2015) (Source: ISTAT 2017)

Definitively, anti- money laundering national legislation has received a fundamental influence by the European law.

Since 1991, UE has approved four Directives (I Directive- 91/308/CEE, II Directive- 2001/97/CE, III Directive2005/60/CE- in Italy D.lsg 231/2007-, IV Directive- 2015/849/CE efficacies from June 2017) that are been adopted by Italian Parliament. We have asserted that the most relevant is the third one that have been adopted in Italy by the D.lgs. 231/2007.

This act, and its implementation, has changed the policies of money laundering contrast: in particular, this law has led to the cooperation of the Italian Financial Intelligence Unit (UIF with domestic i.e. the magistracy, the Bureau of Anti-mafia Investigation and other authorities) and foreign (other FIUs) counterparts and with international organizations such as the FATF. (UIF 2015, 2016a). The last Directive, that will be approved in June 2017, follows the same ideas, but in a stronger way.

By considering the financial data analysis conducted by Italy's Financial Intelligence Unit (UIF), Figure 3 shows a relevant increase of the flow of suspicious transaction reports filed to the Italian antimoney laundering authority between 2012 and the first semester of 2016. In conclusion, it is clear that money laundering is a strong risk in Europe, and only with a common strategy it is possible to contrast it (Gilmour 2016; Yasaka 2017).

\begin{tabular}{|c|c|c|c|c|c|}
\hline & 2012 & 2013 & 2014 & 2015 & 2016- I sem. \\
\hline \multicolumn{6}{|c|}{ Numbers } \\
\hline Suspicious transaction reports received & 67.047 & 64.601 & 71.758 & 82.428 & 52.049 \\
\hline $\begin{array}{l}\text { Suspicious transaction reports transmitted } \\
\text { to investigation authorities }\end{array}$ & 60.078 & 92.415 & 75.857 & 84.627 & 52.343 \\
\hline \multicolumn{6}{|c|}{ Percentage } \\
\hline Suspicious transaction reports received & 36,6 & $-3,6$ & 11,1 & 14,9 & 33,6 \\
\hline $\begin{array}{l}\text { Suspicious transaction reports transmitted } \\
\text { to investigation authorities }\end{array}$ & 96,4 & 53,8 & $-17,9$ & 11,6 & 29,7 \\
\hline
\end{tabular}

Fig. 3. Suspicious transaction reports filed to Italy's Financial Intelligence Unit -2012- I sem. 2016-Isem (Source: UIF 2016b, 2016c, 2016d) 


\section{Theoretical background and hypotheses}

In order to develop some testable hypotheses that guide the empirical analysis, we have considered a set of determinants that include socio-economic, enforcement and crime-specific factors. First, with reference at the principal money laundering literature (Masciandaro 2007; Ahmad 2015; Braun et al. 2016; Ebikake 2016), potential criminals are profit-maximizers who make their decisions on illegal action in order to maximize the expected utility. In particular, criminals commit the crime when the expected benefits of offending are greater than the expected costs of compliance. Assuming that "crime asks crime" and based on a personal consideration, we can assert that countries with a higher rate of criminality continue to increase their level of offences.

Therefore, we may derive the following research hypotheses to be tested empirically.

Hypothesis 1: A lower level of the economic activity leads, ceteris paribus, to a higher (lower) rate of crime.

The literature on the economics of crime has largely stressed the role of the legal income opportunities in affecting the benefits and costs of crime. Theoretically, the relationship between the level (growth) of income and crime is quite ambiguous. On the one hand, higher income opportunities may increase the chances for employment in the legal sector and therefore reduce the crime rate. This statement seems to be supported by the fact that since 2007 in the global economy, as in a "butterfly effect", many types of crimes, and money laundering, have increased as people got poorer and more desperate for money (Rose-Ackerman, Søreide 2013). On the other hand, higher income opportunities makes people better off and, as a result, potentially raise the revenues from crime.

Hypothesis 2: A higher level in education leads, ceteris paribus, to a lower (higher) rate of crime.

Education is an important factor that affects criminal activities. This influence might be either positive or negative for the crime development. On the one hand, higher levels of educational attainment, being associated with higher returns in the labor market, may increase the opportunity cost of criminal behavior. On the other, education may influence personal preferences in a way that affects decisions to engage in crime, bringing about a sort of "civilization" effect (Fajnzylber et al. 2002).

Hypothesis 3: A higher size of the shadow economy, leads, ceteris paribus, to a higher rate of crime.

Institutional factors are an important determinant of crime and of money laundering. For instance, (Vaithilingam, Nair 2007) find less money laundering activity in countries with strong institutional capacity, effective legal and regulatory frameworks, and efficient governance structures. Using the size of the shadow economy as a proxy to measure the efficiency level of the legal framework, we can therefore conjecture that well-established legal and institutional structures promote a more effective contrast of crime behaviour.

Hypothesis 4: A higher size of the gaming and gambling sector leads, ceteris paribus, to a higher rate of crime.

This hypothesis supports the analysis on the money laundering process that takes place, as we have seen before, in three distinct stages: "placement", "layering" and "integration". In particular, the gaming and gambling sector might play an important role in the third section of the "money laundering pyramid"; that is, the integration stage when funds re-enter the legitimate economy (Starola 2012). The Financial Action Task Force (FATF) recognized that gaming and gambling houses represent a great risk for money laundering activities ${ }^{4}$.. Although gaming and gambling rooms are by definition non-financial institutions, they undertake various financial transactions that put them at risk of money laundering. The UK Gambling Commission (UKGC) has communicated that between April 2014 and March 2015 bookmakers filed 633 suspected money laundering operations to the National Crime Agency.

Hypothesis 5: A higher presence of mafia-type organized crime leads, ceteris paribus, to a higher rate of crime.

In Italy, mafia-type organized activities are particularly deep-seated. Ab illo tempore, Italian authorities fight against this type of crime that is strictly related to money laundering. For example, some recent investigations have found that several famous restaurants and hotels in Milan, Turin and other northern cities are becoming 'ndrangheta properties which uses them as fronts for laundering cash. To this purpose, in order to intercept the financial flows of the mafia clans, since 1973 criminal justice authorities have adopted the strategy of the "follow up the money", as suggested by the Italian magistrate (Falcone 2010).

Hypothesis 6: A greater IT environment leads, ceteris paribus, to a higher rate of crime.

The spread of the computer and communication equipment-based information technologies have blurred the boundaries and interconnected national economies. A hyper-connected business ecosystem that frequently straddles national jurisdictions may facilitate the development of new forms of crime (Eurasian Group 2014). In particular, in the last years we have observed the strong increase of the "cybercrime" which has led to the building of an international

\footnotetext{
${ }^{4}$ The Financial Action Task Force (FATF) is an independent inter-governmental body that develops and promotes policies to protect the global financial system against money laundering and terrorist financing.
} 
factory of crime (Castaldo, Naddeo 2010). Some specific features of electronic payment systems may be induce potential money laundering risks. The high speed of transactions, including cross-border money transfers, and the low expenses related to such transactions decrease the cost of money laundering services and may therefore facilitate various money laundering schemes.

Hypothesis 7: The higher rate of corruption leads to, ceteris paribus, a higher rate of crime.

Corruption and money laundering are two intrinsically linked types of crime. Corruption crimes, such as bribery of theft of public funds, are generally committed for the purpose of obtaining private gain. By successfully laundering the proceeds of a corruption offence, the illicit gains may be enjoyed without fear of being confiscated (FAFT 2011). It should be noted that in certain areas the higher the corruption level, "the more ruinous the destruction of the social capital" (Draghi 2011); as a result, corruption may set in motion a vicious circle of social destruction and decay.

Hypothesis 8: The stronger the enforcement and deterrence efforts are, ceteris paribus, the lower is the rate of crime.

Both the theoretical (Becker 1968) and empirical literature (Cohen 2005) have postulated that deterrence variables are important determinants of the expected utility that potential offenders can yield from crime. So, a higher probability of conviction or severity of punishment leads to a reduction in the expected utility from crime and, therefore, less offense will be committed.

\section{Data description and empirical strategy}

Our panel dataset contains annual observations from 20 Italian regions over the period 2008 to 2013 . The dependent variable is the rate of crime measured by the number of money laundering crimes reported to the judicial authorities per 100,000 resident population in each region-year.

Following the main literature on the economics of crime, we include the following variables in our model. First, to address the deterrent effect on criminal behavior, we use the conviction rate defined as the number of defendants convicted by a final judgment per 100,000 resident population in each region-year. We have also considered its squared term in order to control for a possible non-monotonic relation. Moreover, to account for some specific characteristics of money laundering, we use the following variables: i) the number of activities relating to gaming and gambling, ii) the corruption rate, iii) the incidence of mafia, and iv) the degree of information technology (IT) penetration. Finally, we complete our dataset by including some socioeconomic variables that reflect the legal income opportunities of potential criminals. In particular, we insert into our model the rate of real GDP growth, the rate of irregular employment, and the share of population that has completed the university. A detailed description of the variables, their definition as well as the statistical source is provided in Table 1.

Table 1. Definition of variables used (Source: authors)

\begin{tabular}{|c|c|c|}
\hline Variable & Definition & Source \\
\hline Money laundering rate & $\begin{array}{l}\text { The number of money laundering crimes reported to the judicial } \\
\text { authorities per 100,000 resident population in each region-year }\end{array}$ & ISTAT \\
\hline GDP growth & The rate of growth of the real GDP at 2005 constant prices & ISTAT \\
\hline Education & $\begin{array}{l}\text { The number of people with university degree per } 100,000 \text { resident } \\
\text { population in each region-year }\end{array}$ & ISTAT \\
\hline Shadow economy & The rate of irregular employment in each region-year & ISTAT \\
\hline Gaming and gambling & $\begin{array}{l}\text { The number of lottery, bets and game rooms per 100,000 resident } \\
\text { population in each region-year }\end{array}$ & ISTAT \\
\hline IT penetration & $\begin{array}{l}\text { The share of employees that use computers with internet connection in } \\
\text { their work in each region-year }\end{array}$ & ISTAT \\
\hline Incidence of mafia & The ratio of mafia-type crimes over organized crimes in each region-year & ISTAT \\
\hline Corruption rate & $\begin{array}{l}\text { The number of convicted defendants for corruption crime by a final } \\
\text { judgment per 100,000 resident population in each region-year }\end{array}$ & ISTAT \\
\hline Conviction rate & $\begin{array}{l}\text { The number of convicted defendants for money laundering crime by a } \\
\text { final judgment per } 100,000 \text { resident population in each region-year }\end{array}$ & ISTAT \\
\hline
\end{tabular}

Based on the extant literature, we implement in this section a simple crime model (Rickman, Witt 2007; Machin, Meghir 2004). It posits a relationship between the annual reported crime in each region and a set of explanatory variables that are derived by socioeconomic, deterrence and crime-related factors. 
The estimation equation takes the following form:

$$
\text { lnmoneylaundering }_{i t}=a_{0}+\beta \text { lnmoneylaundering }_{i t-1}+X_{i t}^{\prime} \gamma+\text { year }_{t}+\varepsilon_{i t},
$$

where the subscripts $i$ and $t$ represent the region and time period, respectively. The dependent variable (In money laundering) is the crime rate, while the explanatory variables are a set $\mathbf{X}_{\mathbf{i t}}$ of socioeconomic, crime-related specific and deterrence variables. The lagged crime rate in the previous year was inserted into the model in order to identify possible dynamics in crime. As a matter of fact, the economic crime literature has identified the possibility of criminal hysteresis or inertia (Fajnzylber et al. 2002); in other words, higher crime today is associated with higher crime tomorrow. Crimes that were committed in the past may affect current criminal behavior for several reasons. First, criminals can learn by doing, acquiring some level of adequate criminal know-how, which allows them to reduce expected cost of carrying out criminal acts (Case, Katz 1991). Moreover, convicted criminals are likely to have less legal job opportunities, thus reducing their personal cost of participating in criminal activity and making the commission of crime more attractive. Variable year $_{\boldsymbol{t}}$ is a time effect that captures the common variations in crime rates across regions and removes the correlation amongst regions. Finally, $\boldsymbol{\varepsilon}_{i t}$ stands for a well-behaved error term distributed IID $\left(0, \sigma^{2}\right)$. The dependent variables and all explanatory variables were natural logged to alleviate the problem caused by the skewed distributions of some variables. This also simplified calculation of the percentage change of crime rates for a one percent change in each explanatory variable (elasticity). Table 2 summarizes some basic descriptive statistics of the variables used in estimations while Table 3 shows the correlation matrix.

Table 2. Basic descriptive statistics (Source: composed by the authors)

\begin{tabular}{lccccc}
\hline & Obs & Mean & St.Dev. & Min & Max \\
\hline $\begin{array}{l}\text { Money laundering } \\
\text { rate }\end{array}$ & 120 & 2.5341 & 1.8800 & 0.4 & 13.3 \\
Conviction rate & 120 & 1.6033 & 1.7303 & 0 & 9.443 \\
Shadow economy & 120 & 13.802 & 5.6136 & 7.1 & 30.9 \\
Education & 120 & 475.48 & 178.17 & 116.97 & 1202.009 \\
$\begin{array}{l}\text { IT penetration } \\
\text { GDP growth }\end{array}$ & 120 & 25.93818 & 7.799221 & 10.8 & 51,4 \\
Gaming and & 120 & .01196 & .02338 & -.05715 & .0674 \\
gambling & 120 & 75.179 & 125.31 & 3.0636 & 1677.404 \\
Incidence of mafia & 120 & & & 0 & 14.9 \\
Corruption rate & 120 & 1.9036 & 4.1171 & .04131 & 33.344 \\
\hline
\end{tabular}

Table 3. Correlation matrix (Source: composed by the authors)

\begin{tabular}{|c|c|c|c|c|c|c|c|c|}
\hline & $\begin{array}{l}\text { Gaming and } \\
\text { gambling }\end{array}$ & $\begin{array}{l}\text { Corruption } \\
\text { rate }\end{array}$ & Education & Growth & $\begin{array}{l}\text { Shadow } \\
\text { economy }\end{array}$ & $\begin{array}{l}\text { Conviction } \\
\text { rate }\end{array}$ & $\begin{array}{c}\text { IT } \\
\text { penetration }\end{array}$ & $\begin{array}{l}\text { Incidence } \\
\text { of mafia }\end{array}$ \\
\hline $\begin{array}{l}\text { Gaming and } \\
\text { gambling }\end{array}$ & 1.00 & & & & & & & \\
\hline $\begin{array}{l}\text { Corruption } \\
\text { rate }\end{array}$ & -0.06 & 1.00 & & & & & & \\
\hline Education & 0.13 & -036 & 1.00 & & & & & \\
\hline GDP growth & 0.48 & -0.02 & -0.03 & 1.00 & & & & \\
\hline $\begin{array}{l}\text { Shadow } \\
\text { economy }\end{array}$ & -0.13 & 0.04 & -0.06 & -0.09 & 1.00 & & & \\
\hline $\begin{array}{l}\text { Conviction } \\
\text { rate }\end{array}$ & 0.05 & 0.05 & -0.05 & -0.01 & 0.15 & 1.00 & & \\
\hline $\begin{array}{l}\text { IT } \\
\text { penetration }\end{array}$ & -0.15 & 0.26 & -0.31 & -0.09 & -0.04 & -0.21 & 1.00 & \\
\hline $\begin{array}{l}\text { Incidence of } \\
\text { mafia }\end{array}$ & -0.05 & -0.12 & 0.15 & -0.09 & 0.54 & 0.07 & -0.33 & 1.00 \\
\hline
\end{tabular}




\section{Results}

We estimate the balanced panel data linear model using feasible generalized least square (FGLS). Table 4 shows the results of the model applied to all Italian regions during the period from 2008 to 2013. In the estimates for the total country, we observe that the coefficient on the lagged dependent variable is positive and statistically significant. This suggests that money laundering crime is highly persistent over time and may be attributed to the fact that costs of criminal behavior reduce over tine as criminals learn by doing and the moral loss of breaking the law is reduced by crime itself. The conviction rate is positive and statistically significant. This result is quite unexpected and differs from the majority of the existing literature on economics of crime, because the cost of breaking the law should reduce the crime rate. However, a possible explanation may be that deterrence does not yet effectively prevent crime: if deterrence would be stronger, then one would expect to see reduction in the number of money laundering crime. Convictions could be an insufficient indicator for deterrence and the positive significant relationship might reflect the suggestion of previous authors that criminals do not consider the likelihood of the negative consequences of committing a crime. In addition, our findings could mean that criminal sanctions may not be the most effective solution, given the fact that such type of criminals are usually companies for which administrative sanctions and interdiction measures, (i.e., measures that interrupt a company's business) tend to have a stronger deterrent effect than criminal sanctions. However, the negative and significant coefficient of its squared terms reveals the existence of a hump shaped relation between money laundering and law enforcement efforts. Our result indicates that conviction rate exerts its deterrence effect on criminal behavior only after a certain threshold level it has been reached. Thirdly, we find that the number of gaming and gambling halls in the region has a positive effect on money laundering. As we have previously said, these activities are related to various financial operations that put them more and more at risk of money laundering. Fourthly, money laundering tends to be higher in those regions where higher is the rate of corruption. This is in line with a strong empirical evidence showing that corruption and money laundering are intrinsically linked: corruption generates huge proceeds that need to be laundered in order to be given an appearance of legality. Lastly, the empirical analysis indicates that education attainment has a negative and significant effect on the pervasiveness of money laundering at 10 per cent level. The result suggests that higher educated people have higher moral stances that discourage them to participate in illegal criminal activities. Finally, the coefficients on GDP growth rate, incidence of mafia, shadow economy, and IT penetration are not statistically significant.

Table 4. The determinants of money laundering in Italy (Source: composed by the authors)

\begin{tabular}{lcc}
\hline \multicolumn{1}{c}{ Explanatory variables } & Coefficients & Robust standard errors \\
\hline Lagged money laundering rate & $.2318826^{* * *}$ & .0848185 \\
\hline Conviction rate & $.8520366^{* * *}$ & .2051701 \\
Squared conviction rate & $-.2458579^{* *}$ & .1074105 \\
Shadow economy & .0295384 & .1238074 \\
Education & $-.2154139^{*}$ & .1117944 \\
IT penetration & .0332283 & .0534906 \\
GDP growth & .1416273 & 1.740225 \\
Gaming and gambling & $.3760306^{* * *}$ & .0976457 \\
Incidence of mafia & .0072606 & .0354589 \\
Corruption rate & $.1032778^{* * *}$ & .0397394 \\
Constant & .0490129 & 1.287045 \\
\hline Time dummies & Yes & \\
Number of observations & 100 & \\
Wald chi2(12) & 235.27 & \\
\hline$* * * * * *$ indicate statistical significance at the 1,5 and 10 per cent levels. & \\
\hline
\end{tabular}

In order to account for the structural and relevant differences between Italy's north and center on the one hand and the south on the other, we estimated the crime equation for each of these territorial aggregations. For this, we used panel datasets for the 12 regions belonging to the north and center and for the remaining 8 regions belonging to the south of Italy. 
Table 5 displays the coefficient estimates for the northern and center regions. Looking at columns (i) and (ii), we see that the lagged crime rate is now not statistically significant indicating the absence of any persistence in crime. Furthermore, our findings show that law enforcement variables do not lead to significant deterrence of criminal behavior: while the conviction rate is positive and significant, its squared term is not. Moreover, our results show that money laundering in the north-center area is also driven by both the incidence of the mafia-type organized crime and the corruption rate. Several investigations have documented the widespread infiltration of different mafia organizations in the Centre-north regions ${ }^{5}$. However, unlike in the south, where the Mafia has a thorough and sometimes violent control over society, its influence in this area is mainly economic and often hidden. The strong link between organized crime and corruption have been emphasized by the Italy's Financial Intelligence Unit (2015), that has pointed out how corruption has become a means for organized crime to infiltrate the public sector and condition its choices, extending its penetration of the economic and social structure. Particularly interesting is the case of the construction industry. Because of the financial crises, the strong difficulties that have beset construction firms had given mafia families the opportunity to penetrate this sector, which represents an easy place to launder money and to use corruption in public procurement. Finally, education attainment exhibits a negative and a significant effect on the crime rate indicating that, as previously schooling increases the returns to legitimate work, raising the opportunity costs of illicit behavior.

Table 5. The determinants of money laundering at Italian sub-national level (Source: composed by the authors)

\begin{tabular}{|c|c|c|c|c|}
\hline \multirow[b]{2}{*}{$\begin{array}{c}\text { Explanatory } \\
\text { variables }\end{array}$} & \multicolumn{2}{|c|}{ North-Centre of Italy } & \multicolumn{2}{|c|}{ South of Italy } \\
\hline & Coefficients & Robust standard errors & Coefficients & Robust standard errors \\
\hline $\begin{array}{l}\text { Lagged money } \\
\text { laundering rate }\end{array}$ & .1263905 & .1000782 & .2592097 & .1854028 \\
\hline Conviction rate & $.8573544 * * *$ & .2777864 & $1.383742 * * *$ & .3941709 \\
\hline $\begin{array}{l}\text { Squared } \\
\text { conviction rate }\end{array}$ & -.1363101 & .166461 & $-.4696065^{* *}$ & .180609 \\
\hline Shadow economy & .484191 & .40264 & -.0898593 & .7920805 \\
\hline Education & $-.3265024 * * *$ & .1234183 & -.7223074 & .2815605 \\
\hline IT penetration & -.1251508 & .1335918 & .0317984 & .143161 \\
\hline GDP growth & -3.03481 & 3.221425 & 2.020578 & 2.40551 \\
\hline $\begin{array}{l}\text { Gaming and } \\
\text { gambling }\end{array}$ & .2867276 & .2022576 & $.4577015^{* * *}$ & .1442866 \\
\hline Incidence of mafia & $.1832722 * *$ & .0816641 & -.0059865 & .0454134 \\
\hline Corruption rate & $.2278701 * * *$ & .0535571 & .0684227 & .0598178 \\
\hline Constant & -.3241273 & 1.171457 & 3.184613 & 3.917056 \\
\hline Time dummies & Yes & & Yes & \\
\hline $\begin{array}{l}\text { Number of } \\
\text { observations }\end{array}$ & 60 & & 40 & \\
\hline Wald chi2(12) & $133.42 * * *$ & & $79.86^{* * *}$ & \\
\hline
\end{tabular}

The picture slightly changes when we consider empirical results for the southern regions, as displayed in column (iii) and (iv) of Table 5. First, lagged crime rate is again statistically not significant. In addition, as for the deterrence variable, we find that in the southern Italian regions law enforcement measures related to money laundering exerts a significant deterrence effect on criminal behavior only after a certain threshold level it has been reached. In particular, the conviction rate is positive and significant whilst its squared term exerts a negative and statistically significant. Thirdly, the number of gambling and games activities in these regions has a positive and highly significant impact on the pervasiveness of money laundering. In an area where the level of industrial development is low, crime groups find

\footnotetext{
${ }^{5}$ According to the Parliamentary Anti-mafia Commission (2015), "Lombardy, with its capital Milan, is the power hub from which the "Ndrangheta (the Calabrian mafia) has spread throughout northern Italy". For example, Milan and northern Italy are major areas of cocaine and narcotics trafficking.
} 
more profitable to invest and hide their drug or racketeering profits in the gambling industry instead of in the more traditional agriculture or trucking sectors.

\section{Conclusions}

This paper analyzes the determinants of the money laundering in Italy using a panel dataset over the period 20082013. Our empirical results revealed that in most Italian regions enforcement activities do not exert significantly deter criminal behavior. Only very high levels of enforcement efforts reduce money laundering. Moreover, the outcomes show that the major determinants of the money laundering rate differ in Italy between northern-central and southern regions, confirming the existence of a regional dualism. In particular, while in the north-center area the crime rate is negatively related to the level of education and positively to the incidence of mafia and the corruption rate, in southern regions money laundering activities are positively related to the size of the gambling industry. Such a different panorama may be the result of a different strategy of criminal organizations that adapt their schemes to integrate illegal funds into the legal economy to the different economic and social environments. In particular, criminal organizations choose the gambling sector in the less developed areas while in the richest areas they invest in other sectors such as waste management and construction where stronger is the interaction with politicians and, therefore, the probability to undertake corrupt actions.

In conclusion, two main questions arise: are the actual policies to contrast money laundering effective? If they are not, which policies should be adopted? In Italy the reports of suspicious bank transactions have increased substantially in the last years showing not only the FIU's ability to handle the increased flow of information but also to improve its cooperation with domestic and foreign counterparts and with international organizations. However, like in the tale: "The boy who cried wolf", it has been noted (Takàts 2011) that excessive reporting can dilute the information value of report, failing to identify what is truly relevant. Moreover, according to Mafia's prosecutors legalizing gambling in Italy has created new opportunities for the organized crime providing the perfect cash-only business for mobsters, always on the lookout for legal ways to earn and launder money.

In the medium run, we believe that the best strategy to contrast money laundering should allow sound intermediaries to reach a Pareto optimal solution where the benefits (in terms of better reputation and economic incentives) obtained from contrasting criminal behavior should be higher than those obtained by the entry in the crime market.

\section{References}

Ahmad, N. N. 2015 Money laundering using investment companies, Journal of Money Laundering Control 18(4): 438-446. https://doi.org/10.1108/JMLC-10-2014-0031

Becker, G. S. 1968. Crime and punishment: an economic approach, Journal of Political Economics. University of Chicago and National Bureau of Economic Research.

Braun, J.; Kasper, M.; Majdanska, A.; Somare, M. 2016. Drivers of suspicious transaction reporting levels: evidence from a legal and economic prospective, Journal of Tax Administration 2(1): 95-125.

Case, A. C.; Katz, F. L 1991. The company you keep: the effects of family and neighborhood on disadvantaged youths. The National Bureau of Economic Research Working Paper.

Castaldo, A. R.; Naddeo, M. 2010. Prevenzione del riciclaggio ed economic approach: verso una politica criminale integrata?, Il denaro sporco- Prevenzione e repressione nella lotta al riciclaggio, CEDAM. Padova: Italy.

Cohen, M. A. 2005. The costs of crime and justice. New York: Routledge. https://doi.org/10.4324/9780203313145

Draghi, M. 2011. Le mafie a Milano e nel Nord: aspetti sociali ed economici [https://www.bancaditalia.it/pubblicazioni/interventigovernatore/integov2011/draghi-110311.pdf], [cited 11 March 2011]. Available from Internet: www.bancaditalia.it

Ebikake, E. 2016. Money laundering: an assessment of soft law as a technique for repressive and preventive anti-money laundering control, Journal of Money Laundering Control 19(4): 346-375. https://doi.org/10.1108/JMLC-07-2015-0029

Eurasian group on combating money laundering and financing of terrorism 2014. Cybercrime and Money Laundering, New York [http://www.eurasiangroup.org/page_1314698154_47.php], [cited 01 January 2015]. Available from Internet: www.eurasiangroup.com

FAFT. 2011. Laundering the Proceeds of corruption in FAFT Report, Paris [http://www.fatf-gafi.org/media/fatf/documents/ reports/Laundering $\% 20$ the $\% 20$ Proceeds $\% 20$ of $\% 20$ Corruption.pdf], [cited 01 July 2011]. Available from Internet: www.faftgafi.org

Fajnzylber, P.; Lederman, D.; Loayzab, N. 2002. What causes violent crime? European Economic Review 6(7): $1323-1357$. https://doi.org/10.1016/S0014-2921(01)00096-4

Falcone, G. 2010. Tecniche di indagine in materia di mafia. La posta in gioco. Rizzoli. Milano: Italy.

Gilmour, N. 2016. Preventing money laundering: a test of situational crime prevention theory, Journal of Money Laundering Control 19(4): 376-396. https://doi.org/10.1108/JMLC-10-2015-0045

ISTAT. 2017. Judicial Statistics [http://dati.istat.it/], [cited 15 January 2017]. Available from Internet: http://www.istat.it/

Machin, S.; Meghir, C. 2004. Crime and Economic Incentives, Journal of Human Resources 39(4): 958-979. https://doi.org/10.2307/3559034 
Masciandaro, D. 2007. Money Laundering, in Lomborg, B. (Ed.). Solutions for the world's biggest problems: costs and benefits. Cambridge, UK: Cambridge University Press.

Parliamentary Anti-mafia Commission 2015. Secondo rapporto trimestrale sulle aree settentrionali [http://www.cross.unimi.it/secondo-rapporto-trimestrale-sulle-aree-settentrionali/], [cited 10 March 2015] Available from Internet: www.camera.it/

Rickman, N.; Witt, R. 2007. Favouritism and financial incentives: a natural experiment, Economica 75(298): 296-309. https://doi.org/10.1111/j.1468-0335.2007.00605.x

Rose-Ackerman, S.; Søreide, T. 2013. International handbook on the economics of corruption. Vol. 2. Norwegian School of Economics (NHH), Norway.

Schneider, F.; Windischbauer, U. 2010. Money laundering: some facts february, economics of security Working Paper.

Starola, L. 2012. Il riciclaggio nel D.Lgs. 231/2007. Notizie, ambito operativo e soggetti destinatari, Il nuovo diritto delle società 1.

Takàts, E. 2011. A Theory of “Crying Wolf”: The Economics of Money Laundering Enforcement, Journal of Law, Economics, and Organization 27(1): 32-78. https://doi.org/10.1093/jleo/ewp018

UIF. 2015. Rapporto annuale dell'Unità di Informazione Finanziaria 2014. Rome, Italy [https://uif.bancaditalia.it/pubblicazioni/ rapporto-annuale/2015/rapp-annuale-2014.pdf], [cited 02 May 2015]. Available from Internet: www.bancaditalia.it

UIF. 2016a. Rapporto annuale dell’Unità di Informazione Finanziaria 2015. Rome, Italy [https://uif.bancaditalia.it/pubblicazioni/ rapporto-annuale/2016/index.html], [cited cited 07 July 2016]. Available from Internet: www.bancaditalia.it

UIF. 2016b. Quaderni dell'antiriciclaggio- I semestre 2015. Rome, Italy [http://uif.bancaditalia.it/pubblicazioni/quaderni/ 2015/quaderni-1-2015/], [cited 01 October 2015]. Available from Internet: www.bancaditalia.it

UIF. 2016c. Quaderni dell'antiriciclaggio- II semestre 2015. Rome, Italy [https://uif.bancaditalia.it/pubblicazioni/quaderni/ 2015/quaderni-2-2015/index.html], [cited 03 March 2016]. Available from Internet: www.bancaditalia.it

UIF. 2016d. Quaderni dell'antiriciclaggio- I semestre 2016. Rome, Italy [https://uif.bancaditalia.it/pubblicazioni/quaderni/ 2016/quaderni-1-2016/index.html], [cited 03 September 2016]. Available from Internet: www.bancaditalia.it

Vaithilingam, S.; Nair, M. 2007. Factors affecting money laundering: lesson for developing countries, Journal of Money Laundering Control 10(3): 352-366. https://doi.org/10.1108/13685200710763506

Yasaka, N. 2017 Knowledge management in international cooperation for anti-money laundering, Journal of Money Laundering Control 20(1): 27-34. https://doi.org/10.1108/JMLC-09-2015-0040 